J. Clin. Chem. Clin. Biochem.

Vol. 22, 1984, pp. 735-739

\title{
Isolation of a $\beta$-Galactosidase from Chicken Liver
}

\author{
By Shailaja Javeri and G. Uhlenbruck
}

Abteilung für Immunbiologie, Medizinische Universitätsklinik (Leiter: Prof. Dr. med. Volker Diehl) Köln

(Received January 11/August 31. 1984)

This work is dedicated to Prof. Dr. Hans Faillard on occasion of his 60th birthday

Summary: In search of a $\beta$-galactosidase which specifically hydrolyses $\beta 1 \rightarrow 3$ bound galactose residues in galacto-glycoconjugates, an acid $\beta$-galactosidase from chicken liver was investigated. The isolation procedure involved ammonium sulphate precipitation followed by lectin chromatography on Con A-Sepharose 4B, ionexchange chromatography on DEAE-cellulose, gel filtration on Sepharose 6B and affinity chromatography on $p$-aminophenyl-thio- $\beta$ - $D$-galactoside-agarose. The $\beta$-galactosidase was purified 3000 -fold with $11 \%$ recovery of enzyme activity. The purified protein showed an apparent molecular mass of above 200000 in SDSpolyacrylamide gel electrophoresis. A few minor bands were also present. The reduced and denatured $\beta$-galactosidase migrated as a single major band with an apparent molecular mass of 67000 . The enzyme released galactose from lactose and from the synthetic substrates Gal $\beta 1 \rightarrow 3 \mathrm{Gal}, \mathrm{Gal} \beta 1 \rightarrow 6 \mathrm{Gal}$ and Gal $\beta 1 \rightarrow 3 \mathrm{Ara}$. However, the enzyme did not release galactose from the snail gland galactans and the high molecular weight galacto-glycoconjugates and it did not hydrolyse the peanut agglutinin receptor of the red blood cell membrane.

\section{Isolierung einer $\beta$-Galaktosidase aus Hühnerleber}

Zusammenfassung: Auf der Suche nach $\beta$-Galaktosidasen, die spezifisch $\beta 1 \rightarrow 3$ gebundene Galaktosereste hydrolysieren, wie z.B. in verschiedenen Galakto-Glykokonjugaten, wurde eine saure $\beta$-Galaktosidase aus Hühnerleber untersucht. Das Isolierungsverfahren beinhaltete Ammoniumsulfat-Fällung mit anschließender Lektin-Chromatographie an Con A-Sepharose 4B, Ionenaustausch-Chromatographie an DEAE-Cellulose, Gelfiltration an Sepharose 6B und Affinitätschromatographie an $p$-Aminophenyl-thio- $\beta$ - $D$-galaktosid-Agarose. Die $\beta$-Galaktosidase wurde 3000 fach angereichert mit einer verbleibenden Enzymaktivität von $11 \%$. Das gereinigte Protein zeigte in der SDS-Polyacrylamid-Gelelektrophorese ein Molekulargewicht von 200000 Dalton. Zusätzlich traten einige kleinere Banden auf. Nach Reduktion und Denaturierung wanderte die $\beta$-Galaktosidase als eine einheitliche Hauptbande mit einem Molekulargewicht von 67000 Dalton. Das Enzym hydrolysierte Galaktose aus Lactose und aus den synthetisierten Substraten Gal $\beta 1 \rightarrow 3 \mathrm{Gal}$, Gal $\beta 1 \rightarrow$ $6 \mathrm{Gal}$ und $\mathrm{Gal} \beta 1 \rightarrow 3 \mathrm{Ara}$. Die Spaltung von Galaktose aus dem Galaktan der Schneckeneiweißdrüse und aus anderen hochmolekularen Galaktö-Glykokonjugaten war allerdings nicht möglich, und auch der Erdnußagglutinin-Rezeptor der Erythrocytenmembran ließ sich durch das Enzym nicht inaktivieren.

\section{Introduction}

$\beta$-Galactosidases (EC 3.2.1.23) occur ubiquitously in animals, plants and microorganisms (1). They have gained increasing interest, because the inactivation of $\beta$ - $D$-galactosidic lectin receptors in different galacto-glycoconjugates (e.g. the so-called peanut receptor (PNA) or lectins specific for $\mathrm{N}$-acetyl-lactosamine) has become of great importance in immunochemistry, especially with respect to such receptors in tumour cells (2). 
The $\beta$-galactosidase in intestinal mucosa plays a role in the digestion of disaccharides $(3,4)$. Human liver $\beta$-galactosidases (5) like those in mouse (6), feline (7) and dog liver (8) have been investigated with respect to the number of their multiple forms and their diverse substrate specificities.

However, a specific $\beta$-galactosidase for the hydrolysis of macromolecular galactans and membrane-derived or membrane-integrated desialylated galactoglycoconjugates has not yet been found. This report was initiated in search of such a specific $\beta$-galactosidase. In this context, the purification by affinity chromatography and some properties of an acid $\beta$ galactosidase from chicken liver are described.

\section{Materials and Methods}

\section{Materials}

Fresh chicken liver was obtained from the local poultry farm. $o$ Nitrophenyl- $\beta-D$-galactopyranoside was purchased from Serva Feinbiochemica, Heidelberg, FRG. Galactose dehydrogenase and $\mathrm{NAD}^{+}$were obtained from Boehringer, Mannheim, FRG. Con A-Sepharose and Sepharose 6B were bought from Pharmacia, Uppsala, Sweden. Cellulose anion exchanger DE 52 was from Whatman, Kent, U.K. and $p$-aminophenyl-thio- $\beta$ - $D$-galactosideagarose was from Sigma Chemie, München, FRG. Lectins used in the experiments were kindly supplied by Medac, Hamburg, FRG. Tridacnin was purified in our laboratory starting with the crude haemolymph and using acid activated Sepharose 4B for affinity chromatography. The disaccharides $\mathrm{Gal} \beta 1 \rightarrow 3 \mathrm{Gal}$ and $\mathrm{Gal} \beta 1 \rightarrow$ $6 \mathrm{Gal}$ were also synthesized in our laboratory by Dr. F.-G. Hanisch according to 1.c. (19). All other reagents were of analytical grade.

\section{Enrichment of the $\beta$-galactosidase from chicken liver}

All steps were performed at $4^{\circ} \mathrm{C}$. Minced liver tissue $(\sim 400 \mathrm{~g})$ was first homogenized in a Waring Blendor (1 min at high speed)

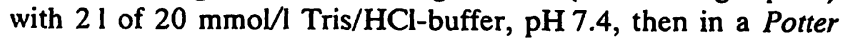
homogenizer. The homogenate was centrifuged for $20 \mathrm{~min}$ at $8000 \mathrm{~g}$. The supernatant was brought to $\mathrm{pH} 5.0$ with $1 \mathrm{~mol} / \mathrm{l} \mathrm{HCl}$ and centrifuged for $20 \mathrm{~min}$ at $15000 \mathrm{~g}$. The resulting supernatant was brought to $\mathrm{pH} 7.4$ with $1 \mathrm{~mol} / 1$ Tris-HCl-buffer, $\mathrm{pH} 8.0$.

\section{Ammonium sulphate precipitation}

The extract of $1400 \mathrm{ml}$ was treated gradually with $465 \mathrm{~g}$ of solid ammonium sulphate then stirred for $30 \mathrm{~min}$. The precipitate was centrifuged for $1 \mathrm{~h}$ at $18000 \mathrm{~g}$, dissolved in $20 \mathrm{mmol} / \mathrm{h} \mathrm{Tris} / \mathrm{HCl}$ $5 \mathrm{mmol} / 1 \mathrm{CaCl}_{2}$-buffer, $\mathrm{pH} 7.4$, and dialysed extensively against the same buffer.

\section{Affinity chromatography on Con A-Sepharose}

Portions of the concentrated enzyme mixture were applied to a $50 \mathrm{ml}$ bed of Con A-Sepharose at a flow rate of $30-40 \mathrm{ml} / \mathrm{h}$. The column was washed with the $20 \mathrm{mmol} / \mathrm{l}$ Tris $/ \mathrm{HCl}-5 \mathrm{mmol} / \mathrm{l}$

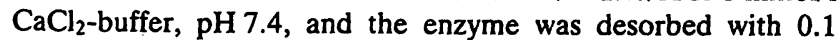
$\mathrm{mol} / \mathrm{l} \alpha$-methylmannoside in the above buffer. The effluents with enzyme activity were pooled.

\section{DEAE-cellulose chromatography}

The Con A-Sepharose purified enzyme was dialysed against 10 mmol/1 sodium phosphate- $10 \mathrm{mmol} / \mathrm{l} \mathrm{NaCl}$-buffer, $\mathrm{pH} 7.4$, then applied to a $2.5 \times 4.0 \mathrm{~cm}$ bed of DE 52-cellulose anion exchanger, previously equilibrated with the same buffer.
The column was washed with the buffer to remove the unbound protein followed by batchwise elution with $50 \mathrm{mmol} / \mathrm{t}, 150$ $\mathrm{mmol} / \mathrm{h}$ and $500 \mathrm{mmol} / / \mathrm{NaCl}$ in the buffer. The $\beta$-galactosidase activity was found in the pool eluted with $150 \mathrm{mmol} / \mathrm{A} \mathrm{NaCl}$.

\section{Sepharose $6 B$ chromatography}

The $\beta$-galactosidase active pool from the 'previous step was concentrated and dialysed against $10 \mathrm{mmol} / 1$ sodium phosphate$500 \mathrm{mmo} / \mathrm{/} \mathrm{NaCl}-0.2 \mathrm{~g} / 1 \mathrm{NaN}_{3}$-buffer, $\mathrm{pH}$ 7.0. It was applied to a $1.6 \times 90 \mathrm{~cm}$ column of Sepharose $6 \mathrm{~B}$ and eluted at a flow rate of 9 $\mathrm{ml} / \mathrm{h} .3 \mathrm{ml}$ fractions were collected. The enzymically active fractions were pooled and dialysed against $50 \mathrm{mmol} / \mathrm{T}$ Tris $/ \mathrm{HCl}-100$ $\mathrm{mmol} / 1 \mathrm{NaCl}-10 \mathrm{mmol} / / \mathrm{MgCl}_{2}$-buffer, $\mathrm{pH}$ 7.0.

Affinity chromatography on p-aminophenyl-thio- $\beta$ - $D$-galactosideagarose

The dialysed $\beta$-galactosidase pool was applied at the rate of 30 $\mathrm{ml} / \mathrm{h}$ to $10 \mathrm{ml}$ of the affinity matrix, previously equilibrated with the last buffer of dialysis. After the unbound protein had been eluted with this same buffer, the bound $\beta$-galactosidase was eluted with $0.1 \mathrm{~mol} / 1$ borate buffer, $\mathrm{pH} 10.5$. The enzyme was concentrated in a Minicon concentrator then dialysed against $20 \mathrm{mmol} / \mathrm{l}$ Tris/HCl-buffer, $\mathrm{pH}$ 7.0. Protein was estimated by the method of Lowry et al. (9) using bovine serum albumin as a standard.

\section{$\beta$-Galactosidase catalytic activity}

$\beta$-Galactosidase catalytic activity was measured by the degradation of the synthetic compound $o$-nitrophenyl- $\beta-D$-galactopyranoside, using a modification of the procedure of Hughes \& Jeanloz (10). The reaction mixture contained $10 \mu \mathrm{mol}$ of the substrate in $1.0 \mathrm{ml}$ Mcllvaine-buffer ( $0.1 \mathrm{~mol} / \mathrm{l}$ citric acid- $0.2 \mathrm{~mol} / 1 \mathrm{Na}_{2} \mathrm{HPO}_{4}$, $\mathrm{pH} 4.0), 0.9 \mathrm{ml}$ of the same buffer and $0.1 \mathrm{ml}$ of the enzyme solution. Incubation was for $60 \mathrm{~min}$ at $37^{\circ} \mathrm{C}$. The reaction was stopped by the addition of $2 \mathrm{ml}$ of $0.2 \mathrm{~mol} / / \mathrm{Na}_{2} \mathrm{CO}_{3} / \mathrm{NaHCO}_{3}$ buffer, $\mathrm{pH} 10.8$. The absorbance of the $o$-nitrophenol liberated during the enzyme-catalysed hydrolysis was measured at $420 \mathrm{~nm}$. The unit of $\beta$-galactosidase catalytic activity is equivalent to the amount of enzyme which releases $1 \mu \mathrm{mol}$ of $o$-nitrophenol per minute under the given conditions. The hydrolysis of galactose from the disaccharide and galactan was assayed by the oxidation of galactose with galactose dehydrogenase and $\mathrm{NAD}^{+}$by a standard procedure (11). The increment of the absorbance of NADH at $340 \mathrm{~nm}$ is proportional to the amount of galactose hydrolysed.

\section{Further characterization}

The purity of the protein was determined by polyacrylamide gel electrophoresis on $10-20 \%$ gradient gels in the presence of $10 \mathrm{~g} / 1$ sodium dodecyl sulphate and $50 \mathrm{~g} / \mathrm{l}$-mercaptoethanol, modified from the methods of Laemmli (12) \& Anderson (13). Haemagglutination tests and the enzyme treatment of the cells were performed by established methods (14).

\section{Results}

Isolation and partial purification of a $\beta$-galactosidașe from chicken liver

The purification of a $\beta$-galactosidase from chicken liver is summarized in table 1 . The enzyme was purified 3000 -fold with a recovery of $11 \%$ of the original activity. Due to its glycoprotein nature, the $\beta$-galactosidase was quantitatively adsorbed to a column of immobilized Concanàvalin A. During the elution of the enzyme with $0.1 \mathrm{~mol} / \mathrm{l} \alpha$-methylmannoside from the Con A-Sepharose column, the $\beta$-galactoside activity coeluted with the protein peak giving a good 
Tab. 1. Purification of $\beta$-galactosidase from chicken liver.

\begin{tabular}{|c|c|c|c|c|}
\hline \multirow[t]{2}{*}{ Purification Step } & \multicolumn{4}{|c|}{ Chicken liver } \\
\hline & $\begin{array}{l}\text { Total } \\
\text { protein } \\
\text { (mg) }\end{array}$ & $\begin{array}{l}\text { Total } \\
\text { activity } \\
\text { (units) }\end{array}$ & $\begin{array}{l}\text { Specific } \\
\text { activity } \\
\text { (units/mg) }\end{array}$ & $\begin{array}{l}\text { Re- } \\
\text { cov- } \\
\text { ery } \\
(\%)\end{array}$ \\
\hline 1. Homogenate & 38330 & 11.5 & 0.0003 & 100 \\
\hline $\begin{array}{l}\text { 2. Ammonium } \\
\text { sulphate } \\
\text { precipitation }\end{array}$ & 577 & 7.5 & 0.0013 & 65 \\
\hline $\begin{array}{l}\text { 3. Con } \\
\text { A-Sepharose }\end{array}$ & 547 & 8.2 & 0.015 & 71 \\
\hline $\begin{array}{l}\text { 4. DEAE- } \\
\text { Cellulose }\end{array}$ & 90.5 & 3.8 & 0.042 & 33 \\
\hline 5. Sepharose 6B & 12.6 & 2.9 & 0.23 & 25 \\
\hline $\begin{array}{l}\text { 6. Amino- } \\
\text { phenyl- } \beta-D \text { - } \\
\text { thiogalactoside- } \\
\text { agarose }\end{array}$ & 1.5 & 1.3 & 0.9 & 11 \\
\hline
\end{tabular}

recovery of the enzyme (fig. 1). The protein was subjected to DEAE-cellulose chromatography and the $\beta$-galactosidase active protein desorbed with 150 $\mathrm{mmol} / / \mathrm{NaCl}$ in the elution buffer and with a loss of $50 \%$ of the enzyme activity from the previous step. No charge isomers of the enzyme were observed. In some experiments this step was completely omitted, as it leads to a considerable loss of the enzyme activity. In this case the overall yield and the purity of the enzyme remained nearly unchanged.

Further purification of the enzyme on Sepharose 6B indicated only one peak of $\beta$-galactosidase catalytic activity, which did not coincide with the broad protein peak (fig. 2). The activity fractions finally purified on the $p$-aminophenyl-thio- $\beta$ - $D$-galactoside-agarose column (fig. 3 ) showed a catalytic activity concentration of $900 \mathrm{U} / \mathrm{l}$. It was stored frozen at $-20^{\circ} \mathrm{C}$ in $20 \mathrm{mmol} / 1$ Tris/HCl-buffer, $\mathrm{pH}$ 7.0. Under these conditions no loss of activity was noticed during a 2 month period.

\section{SDS-polyacrylamide gel electropharesis}

On polyacrylamide gel electrophoresis with $10 \mathrm{~g} / \mathrm{l}$ sodium dodecyl sulphate in $10-20 \%$ gradient gels a major protein band was found. This was visually estimated to be $90 \%$ of the protein, with a molecular mass above 200000 . Nevertheless, the preparation also exhibited several minor bands with molecular masses of $91000,60000,38000$ and 28000 . Reduced (50 g/ $\beta$-mercaptoethanol) and denaturated protein showed an additional band of molecular mass of 67000 (fig. 4).

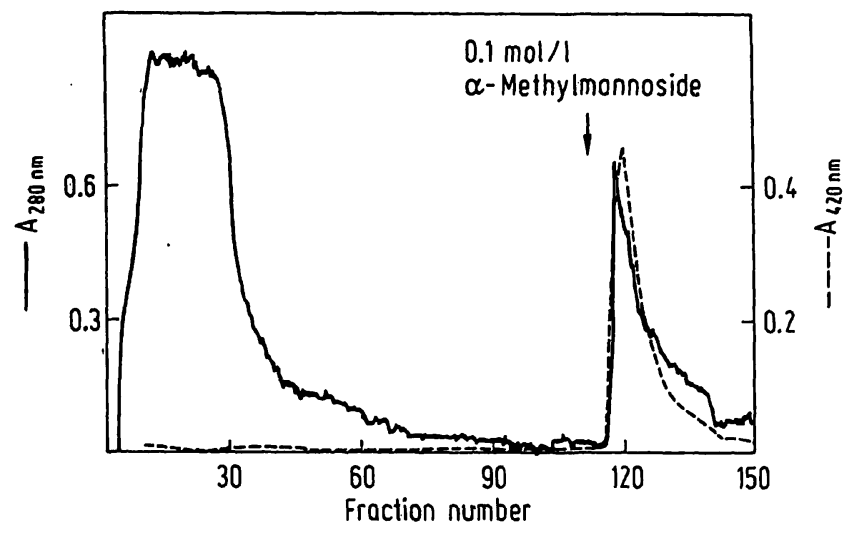

Fig. 1. Affinity chromatography on Con A Sepharose of chicken liver proteins prepared by ammonium sulphate precipitation.

- protein content $\quad---$ enzyme catalytic activity.

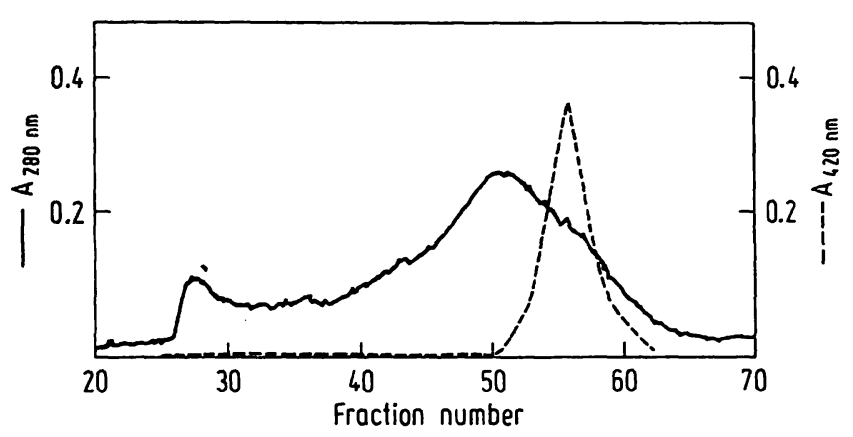

Fig. 2. Sepharose 6B chromatography of partially purified chicken liver $\beta$-galactosidase.

- protein content - - enzyme catalytic activity.

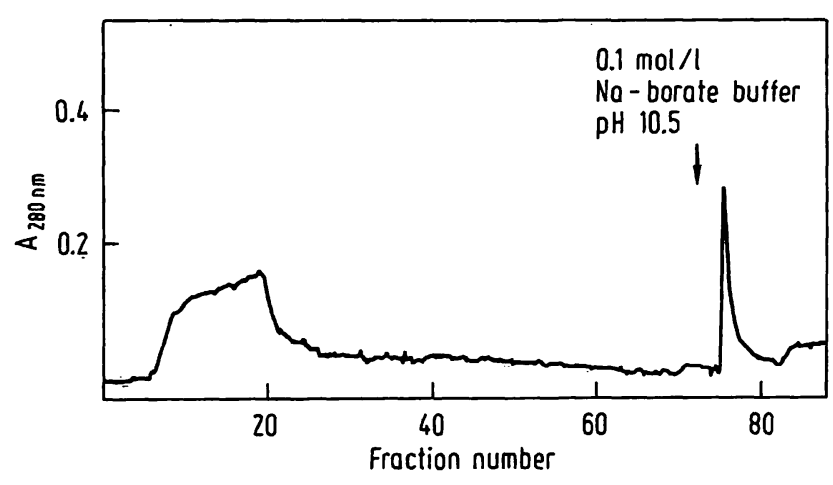

Fig. 3. Elution of chicken liver $\beta$-galactosidase from $p$-aminophenyl- $\beta-D$-thiogalactoside agarose with $0.1 \mathrm{~mol} / /$ borate buffer, $\mathrm{pH}$ 10.5. Enzyme catalytic activity coeluted with the protein peak.

\section{pH-Optimum}

The pH-optimum of the hydrolysis of the chromogenic substrate $o$-nitrophenyl- $\beta-D$-galactopyranoside by the $\beta$-galactosidase was 4.0. The optimal activity was determined in McIlvaine buffers $(0.1 \mathrm{~mol} / \mathrm{l}$ citric acid- $0.2 \mathrm{~mol} / \mathrm{h} \mathrm{Na} \mathrm{HPO}_{4}$ ) in the range $\mathrm{pH} 3.0$ to 8.0, using samples with the same initial activity. All assays were performed at $37^{\circ} \mathrm{C}$ for $60 \mathrm{~min}$ at a $\mathrm{pH}$ of 4.0. An apparent Michaelis constant $\left(K_{\mathrm{m}}\right)$ of $5.6 \times 10^{-4} \mathrm{~mol} / / \mathrm{w}$ was determined. 


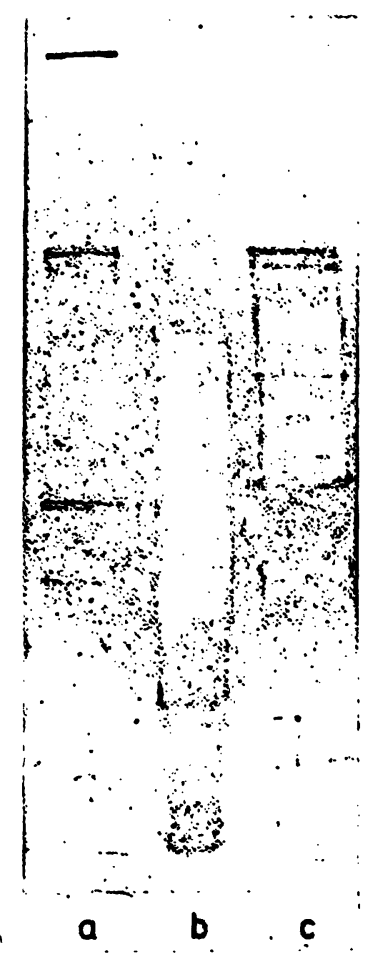

Fig. 4. Polyacrylamide gel electrophoresis of the purified chicken liver $\beta$-galactosidase on $10-20 \%$ gradient gels in the presence of $10 \mathrm{~g} / 1 \mathrm{SDS}$.

a: purified $\beta$-galactosidase

b: marker proteins

c: $\beta$-galactosidase reduced with $5 \mathrm{~g} / 1 \beta$-mercaptoethanol.

\section{Substrate specificity}

The $\beta$-galactosidase showed complete hydrolysis of the $\beta 1 \rightarrow 4$ linkage of lactose. Similarly, the $\beta$-galactosidase hydrolysed the $\beta$-linked synthetic disaccharide substrates, Gal $\beta 1 \rightarrow 3 \mathrm{Gal}, \mathrm{Gal} \beta 1 \rightarrow 6 \mathrm{Gal}$ and Gal $\beta 1 \rightarrow 3$ Ara, whereas the $\alpha$-linked galactoside mellibiose was not attacked under the same conditions. The apparent Michaelis constants for the substrates are presented in table 2.

Tab. 2. Michaelis constants $K_{\mathrm{m}}$ for several disaccharide substrates.

\begin{tabular}{ll}
\hline Disaccharides & $K_{\mathrm{m}}(\mathrm{mol} / \mathrm{l})$ \\
\hline 1. O- $\beta-D-$ Gal $1 \rightarrow 4-D$-Glu (lactose) & $1.85 \times 10^{-2}$ \\
2. O- $\beta-D$-Gal $1 \rightarrow 3-D$-Gal & $1.43 \times 10^{-2}$ \\
3. O- $\beta-D$-Gal $1 \rightarrow 3-D$-Ara & $1.48 \times 10^{-2}$ \\
4. O- $\beta-D-$ Gal $1 \rightarrow 6-D$-Gal & $1.18 \times 10^{-2}$
\end{tabular}

However, no hydrolysis of the galactan of Helix pomatia snail glands was observed. Increase in the incubation time from $1 \mathrm{~h}$ to $6 \mathrm{~h}$ had no effect on the cleavage of the galactose from the galactan. There was no difference in the absorbance at $340 \mathrm{~nm}$ mediated by the increase in NADH concentration after the action of galactose dehydrogenase on liberated galactose.

\section{Haemagglutination tests}

In haemagglutination tests normal and neuraminidase-treated red blood cells were agglutinated by $\beta$ $D$-galactose-specific lectins like Ricinus communis I, Arachis hypogaea, Maclura pomifera and Tridacnin lectins. Normal and neuraminidase-treated cells were further incubated with the active $\beta$-galactosidase at $37^{\circ} \mathrm{C}$ for $2 \mathrm{~h}$. No difference in the results of haemagglutination tests of $\beta$-galactosidase-treated and -untreated normal and desialylated red blood cells was observed, indicating the absence of any action by the enzyme.

\section{Discussion}

Affinity column chromatography has been used for the purification of different $\beta$-galactósidases (4-7). The chicken liver $\beta$-galactosidase purification procedure described here with ammonium sulphate precipitation, Con A-Sepharose-, DEAE-cellulose-, Sepharose 6B-chromatography and finally $p$-aminophenyl-thio- $\beta-D$-galactoside-agarose chromatography permits the isolation of the enzyme with a relative high degree of purity. The Con A-Sepharose chromatography step and the precipitin reactions with Con A and Ricinus communis I confirm the glycoprotein nature of the enzyme. DEAE-cellulose chromatography may allow a good resolution of charge isomers, but in this case there was no evidence for the presence of such isomers. A loss of more than $50 \%$ of the enzyme catalytic activity indicates that some other ion exchange chromatography step should be introduced for such a purification. Similarly, it would be preferable to avoid the drastic increase of the $\mathrm{pH}$ of the borate buffer to 10.4 in the elution of the enzyme from the affinity column, but lower $\mathrm{pH}$ 's gave unsatisfactory results.

Electrophoresis of the enzyme on SDS/polyacrylamide slab gels gave a major band of molecular mass greater than 200000 , which with $50 \mathrm{~g} / 1$ mercaptoethanol reduction showed a band with a molecular mass estimated at 67000 . Some of the several minor bands could represent the "protective factor" and "neuraminidase subunit" proteins, which have been reported to copurify with acid $\beta$-galactosidase from other species $(15,16)$. The presence of other enzymes was, however not examined, but should have been revealed in the haemagglutination tests. The electrophoretic patterns as a function of acrylamide concentration should be examined further to obtain a better insight into the protein components of this $\beta$-galactosidase preparation.

The $\beta$-galactosidase showed broad substrate specificity; terminal non-reducing gälactose residues were 
removed from lactose, $\mathrm{Gal} \beta 1 \rightarrow 3 \mathrm{Gal}, \mathrm{Gal} \beta 1 \rightarrow 6 \mathrm{Gal}$ and $\mathrm{Gal} \beta 1 \rightarrow 3 \mathrm{Ara}$ and the chromogenic substrate $o$ nitrophenyl- $\beta-D$-galactopyranoside. However, the cleavage of galactose from the snail albumin gland galactan did not occur, even with a longer incubation time of $6 \mathrm{~h}$. Prolonged incubation over days may be necessary for the $\beta$-galactosidase to reach the terminal galactose residues of the macromolecule. Haemagglutination tests of normal, desialylated and $\beta$ galactosidase-treated red blood cells with different galactose-specific lectins like Ricinus communis I, Arachis hypogaea, Maclura pomifera and Tridacnin lectins showed no marked difference. This indicates that the enzyme cannot hydrolyse the terminal lectin receptors on the red blood cell membrane galactoglycoconjugates.

\section{References}

1. Wallenfels, K. \& Malhotra, O. P. (1961) Advan. Carbohyd. Chem. 16, 239-298.

2. Klein, P. J., Vierbuchen, M., Fischer, J., Würz, M., Uhlenbruck, G. \& Schulz, K. D. (1983) In: Immunologie und Tumormarker beim Mammakarzinom (U. D. Koenig, ed.) pp. 67-77, Ferdinand Enke Verlag, Stuttgart.

3. Gray, G. M. \& Santiago, N. A. (1969) J. Clin. Invest. 48 , 716-728.

4. Jackson, W. P. U. (1952) Clin. Sci. 11, 209-216.

5. Frost, R. G., Holmes, E. W., Norden, A. G. \& O'Brien, J. S. (1978) Biochem. J. 175, 181-188.

6. Tomino, S. \& Meisler, M. (1975) J. Biol. Chem. 250, 77527758.

7. Holmes, E. W. \& O'Brien, J. S. (1979) Biochemistry 18, 752-758.

8. Hubert, J. J. \& O'Brien, J. S. (1983) Biochem. J. 213, 473478.

9. Lowry, O. H., Rosebrough, N. J., Farr, A. L. \& Randall, R. J. (1951) J. Biol. Chem. 193, 265-275.

10. Hughes, R. C. \& Jeañloz, R. W. (1964) Biochemistry 3, $1535-1542$.
In conclusion, the $\beta$-galactosidase isolated from the chicken liver is not suitable for the hydrolysis of galactose terminal lectin receptors on macromolecular galacto-glycoconjugates and on cell surfaces like red blood cell membranes. Obviously, the cleavage of terminal macromolecular $\beta$-glycosidically bound $D$ galactose is very resistant to most $\beta$-galactosidases, except a few enzymes of bacterial origin. Recently, the endo- $\beta$-galactosidase of Bacteroides fragilis has been shown to hydrolyse internal $\beta$-galactosidic linkages of oligosaccharides belonging to the poly $\mathrm{N}$ acetyl-lactosamine series (18), whereas $\beta$-galactosidase isoenzyme from Turbo cornutus has been described with substrate specificity towards a ganglioside with terminal $\beta 1 \rightarrow 3$ linked galactose (20).

11. Bergmeyer, H. U. (1970) Methoden der enzymatischen Analyse, Verlag. Chemie, Weinheim.

12. Laemmli, U. K. (1970) Nature 277, 680-685.

13. Anderson, L. \& Anderson, N. G. (1977) Proc. Nat. Acad. Sci. USA 74, 5421-5425.

14. Uhlenbruck, G., Baldo, B. A. \& Steinhausen, G. (1975) Z. Immun. Forsch. 150, 354-363.

15. Rodriguez-Berrocal, F. J., Perez-Gonzalez, M. N. \& Cabezas, I. A. (1983) Enzyme 30, 196-204.

16. D'Azzo, A. D., Hoogeveen, A., Reuser, A. I. I., Robinson, D. \& Galjaard, H. (1982) Proc. Nat. Acad. Sci. USA 19, 4535-4539.

17. Verheijen, F., Brossmer, R. \& Galjaard, H. (1982) Biochem. Biophys. Res. Commun. 108, 868-875.

18. Scudder, P., Uemura, K., Dolby, I., Fukuda, M. N. \& Feizi, T. (1983) Biochem. J. 213, 485-494.

19. Benzing-Nguyen, L. \& Roden, L. (1977) Carbohydr. Res. $53,123-128$.

20. Yeung, K. K., Owen, A. J. \& Dain, J. A. (1983) Comp. Biochem. Physiol. 76, 619-626.

Prof. Dr. med. Gerhard Uhlenbruck Dr. rer. nat. Shailaja Javeri Abteilung für Immunbiologie Medizinische Universitätsklinik Köln Kerpener Straße 15 D-5000 Köln 41 
-
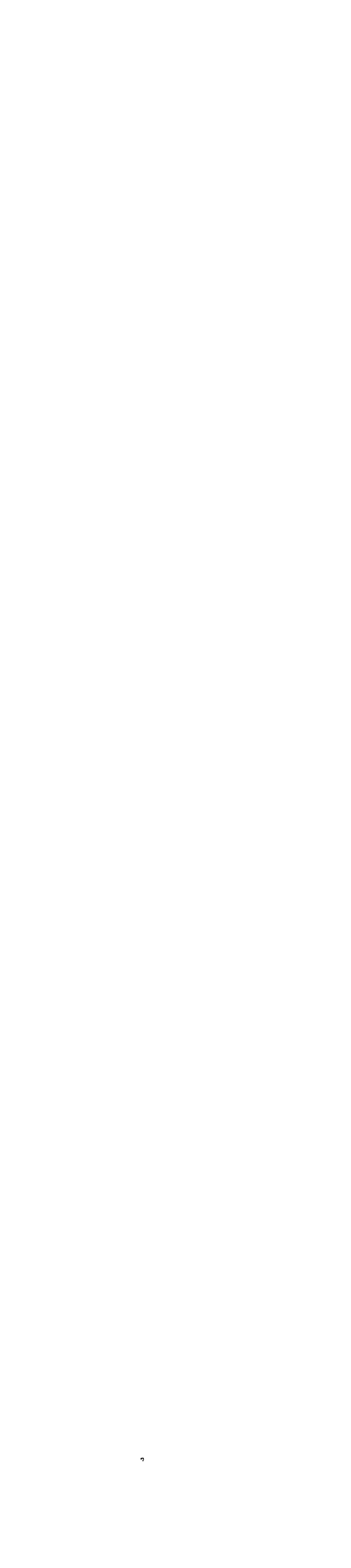